\title{
PHYSICOMECHANICAL PROPERTIES OF HIGH AND LOW DENSITY POLYETHYLENE MIXTURES AND MODIFIED COMPOSITIONS ON THEIR BASIS
}

\author{
F.A. Mustafayeva, N.T. Kakhramanov, I.A. Ismayilov, L.Kh. Khamedova, \\ * G.S. Martynova \\ Institute of Polymer Materials \\ National Academy of Sciences of Azerbaijan \\ 124, S. Vurgun str., Sumgait, AZ 5004 \\ * Oil and Gas Institute \\ National Academy of Sciences of Azerbaijan \\ 9, F.Amirov str., Baku, AZ1000, Azerbaijan \\ e-mail:najaf1946@ rambler.ru
}

Received 18.07.2020

Accepted 25.09.2020

\begin{abstract}
The paper considers the influence of the ratio of polymer components - high density polyethylene and low density polyethylene, on the main physicomechanical properties. The properties of polymer mixtures such as tensile yield stress, ultimate tensile stress and elongation at break were studied. It revealed that as the content of low density polyethylene in the polymer mixture increases, two small maxima appear on curves. These maxima correspond to 5.0 and $50 \mathrm{wt}$. \% of the content of low density polyethylene in the mixture. The loading of $1.0 \mathrm{wt}$. \% of a structurant-titanium dioxide into the composition of polymer mixtures leads to noticeable increase in their strength indicators and elongation at break at almost all ratios of polymer components. The effect of the crosslinking agent, sulfur, on the basic physicomechanical and thermophysical properties of composite materials was examined. It found that as the sulfur content rose from 1.0 to $5.0 \mathrm{wt} . \%$ in the polymer mixture, a regular increase in the tensile yield strength, elongation at break, and heat resistance of the samples is observed. Along with this, a slight decrease in the melt flow rate of polymer compositions with an increase in the concentration of the curing agent was noted. The theoretical substantiation of processes occurring in polymer mixtures in the process of exposure to titanium dioxide and sulfur was presented.
\end{abstract}

Keywords: low density polyethylene, high density polyethylene, structurant, vulcanization, heat resistance, melting point, sulfur.

DOI: $10.32737 / 2221-8688-2020-3-336-342$

\section{Introduction}

In the process of improving the density polyethylene (HDPE) and low density technique and technology of industrial polyethylene (LDPE) are among the most largeproduction, increased demands are made on the quality of structural polymer materials. For this purpose, homo- and copolymers produced in the industry began to undergo various types of modification using structure-forming agents, plasticizers, fillers, cross-linking agents, compatibilizers, allowing to a certain extent to improve the basic physicomechanical and operational characteristics of composite materials [1-4]. Despite a large number of works in this direction, studies based on mixtures of the same type of polymers are very limited. For example, it is known that high tonnage polyolefins produced in the industry. However, despite this, the literature contains a very small number of studies devoted to the study of a mixture of polyethylene. Obtaining structural materials based on mixtures of polyethylene is the simplest way to obtain a set of various types of compositions differing in their physicomechanical characteristics [5-7]. [5-7].

In the light of the foregoing, the purpose of the work is to develop and analyze composite materials based on mixtures of high and low density polyethylene. 


\section{Experimental part}

The main objects of the study were:

LDPE with a density of $912 \mathrm{~kg} / \mathrm{m}^{3}$, an ultimate tensile stress of $10.25 \mathrm{MPa}$, an elongation at break of $800 \%$, a melt flow index (MFI) of $5.8 \mathrm{~g} / 10 \mathrm{~min}$.

HDPE with a density of $963 \mathrm{~kg} / \mathrm{m}^{3}$, ultimate tensile stress of $31.8 \mathrm{MPa}$, elongation at break of $200 \%, \mathrm{MFI}=8.4 \mathrm{~g} / 10 \mathrm{~min}$. $\left(\mathrm{TiO}_{2}\right)$.

Structuring agent - titanium dioxide

The vulcanizing agent-sulfur is a chemical element with atomic number 16 . Elemental sulfur is a bright yellow crystalline solid at room temperature. Under normal conditions, sulfur atoms form cyclic octatomic molecules with the chemical formula $\mathrm{S}_{8}$. Used as a polymer vulcanization agent.
The melt flow index (MFI) was determined on a MELT FLOW TESTER, CEAST MF50 rheometer (INSTRON, Italy) at a temperature of $190^{\circ} \mathrm{C}$ and a load of $5 \mathrm{~kg}$.

LDPE and HDPE-based polymer compositions were obtained in the process of mixing on rollers at a temperature of $170^{\circ} \mathrm{C}$.

Heat resistance was determined by the Vicat method.

Ultimate tensile stress $\left(\sigma_{\mathrm{u}}, \mathrm{MPa}\right)$, tensile yield stress $\left(\sigma_{\mathrm{y}}, \mathrm{MPa}\right)$ and elongation at break $(\varepsilon, \%)$ were determined in accordance with GOST 11262-80.

Melting points were determined on a Q1500 D derivatograph (MOM, Hungary) of the Paulik-Paulik-Erdey system.

\section{Results and discussion}

In practice, depending on the type and purpose of structural products, an important point is the selection and use of polymers of varying degrees of crystallinity and density. HDPE is a high strength and tough polymer, while LDPE is of a relatively low strength and elastic polymer. Moreover, they differ sharply not only in their strength, but in their thermophysical characteristics as well. In the development of structural products, a significant need arises for the use of polymers that would have a sufficiently high strength and concurrently a satisfactory elasticity. In this regard, the use of polyethylene mixtures makes it possible to obtain a whole range of polymeric materials and related products with various combinations of density and degree of crystallinity. This method is distinguished by the simplicity of the technological solution and can be implemented in nearly all large and small enterprises on plastic processing [1-3, 8].

At the same time, studies aimed at the use of various ingredients, for example, structure-forming agents or cross-linking agents, on the nature of changes in the main physicomechanical and thermophysical properties of polyethylene mixtures, are of great importance. For this, Fig. 1 shows the regularity of changes in strength properties ultimate tensile stress (Fig. 1.1), tensile yield stress (Fig. 1.1') and elongation at break (Fig. 1.3) of polymer mixtures depending on the ratio of HDPE / LDPE mixture components. The same figure shows the results of studying the effect of the structurant $\left(\mathrm{TiO}_{2}\right)$ and the ratio of the mixture components (HDPE / LDPE) on the ultimate tensile stress (Fig. 1.2), tensile yield stress (Fig. 1.2') and elongation at break (Fig. 1.4) of modified compositions. Analysis of curves in this figure makes it possible to establish that the nature of changes in the tensile yield stress $\left(\sigma_{\mathrm{y}}\right)$ and ultimate tensile stress $\left(\sigma_{\mathrm{u}}\right)$ of polymer mixtures from the HDPE / LDPE ratio occurs according to a certain curvilinear regularity. These curves show two small maxima: at the minimum concentration of LDPE (5.0 wt. \%) and at $50 \mathrm{wt} . \%$ of its content in the mixture.

To answer the cause-and-effect peculiarities of the origin of these strength maxima, let us turn to the processes occurring in the deformation of thermoplastics. The appearance of a maximum at $5.0 \mathrm{wt}$ \% LDPE content can be associated with a special form of packing of LDPE macrochains in the HDPE polymer medium. Both polyethylenes under consideration are electrically neutral and very close to each other, both in composition and structure, and therefore, we believe that to assert about some classical formation of the dispersed 
phase of LDPE in the dispersed medium of HDPE will be unjustified. It has to be kept in mind that LDPE is one of the more branched polyethylenes in comparison with HDPE. The branching structure of LDPE, in fact, provides it with a relatively high flexibility and low crystallinity (54\%). It is also known that in the interspherolite region there are "through-chains" which are responsible for strength and deformation properties of the polymer. In the process of uniaxial deformation within 3-5\%, the primary load is directed to the expansion of spherulites which, in terms of strength, is characterized by the tensile yield stress. Further stretching of the samples is already associated with the formation of a "neck" the strength of which is considered as ultimate tensile stress [9$11]$.

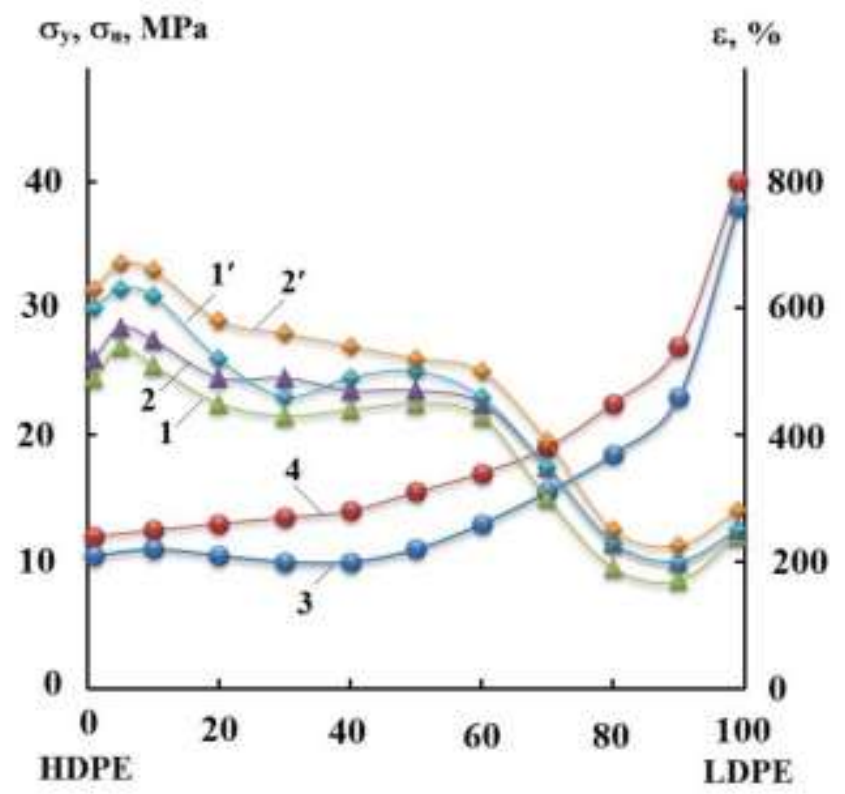

Fig. 1. Effect of HDPE / LDPE ratio on ultimate tensile stress $\left(\sigma_{\mathrm{u}}\right)(1.2)$, tensile yield strength $\left(\sigma_{\mathrm{y}}\right)$ $\left(1^{\prime}, 2^{\prime}\right)$ and elongation at break (3.4) of composite materials based on the initial mixture of HDPE + LDPE $\left(1,1\right.$ ', 3) and its modified $\mathrm{TiO}_{2}$ compositions $(2,2 ', 4)$.

We believe that the loading of up to $5.0 \%$ LDPE will testify to the fact that the branched part of the macrochain will be redistributed mainly in the interspherolite region of HDPE, providing a partial removal of rigidity in it and thereby increasing the probability of simultaneous participation of the most of the passage chains in the process of uniaxial deformation. We believe that this is how one can interpret a certain increase in the strength characteristics of the mixture at a minimum concentration of LDPE. A further increase in the concentration of LDPE results in a decrease of the degree of composition crystallinity of compositions with a subsequent decrease in their strength parameters. It is characteristic that

at low LDPE concentrations in the composition of the HDPE + LDPE mixture, the difference between the values of $\sigma_{\mathrm{y}}$ and $\sigma_{\mathrm{u}}$ is greater than those at a high LDPE content. The data obtained once again confirm our statement that as the concentration of LDPE in the mixture rises, the plasticity of the composite material decreases due to the increase in its flexibility and elasticity. Some increase in strength characteristics at $50 \mathrm{wt}$. \% content of LDPE in the mixture, in all likelihood, can be interpreted with some approximation by phase inversion. In contrast to strength indicators, the elongation monotonically increases as the content of LDPE in the mixture rises.

The same Fig. 1 shows the curves of the dependence of the tensile yield stress (curve 1.2'), ultimate tensile stress (curves 1.2) and elongation at break (curve 1.4) of HDPE + LDPE polymer blends containing $1.0 \%$ of a structurant-titanium dioxide. A comparative analysis of the curves in this Fig. reveals that 
the loading of titanium dioxide contributes to a noticeable improvement in the strength properties and elongation at break of polymer mixtures. In this case, such an essential increase in these indicators unambiguously testifies to the fact that the loading of a structurant-titanium dioxide promotes the formation of heterogeneous nucleation centers. Simultaneous growth of crystalline formations during cooling on homogeneous and heterogeneous nucleation centers contributes to the formation of smallspherolite formations which, in turn, results in an increase in the strength characteristics of composite materials [12]. A characteristic point is that in this case, at $5.0 \mathrm{wt}$ \% LDPE in the composition, a slight increase in the values of $\sigma_{\mathrm{y}}$ and $\sigma_{\mathrm{u}}$ is observed. At the same time, at $50 \mathrm{wt}$. $\%$ LDPE content, the second maximum of strength characteristics is not observed. There is a reason to believe that the appearance of heterogeneous crystallization centers in the presence of titanium dioxide and the formation of a small-spherolite supramolecular structure lead to a relatively uniform mutual dispersion of mixture components. The latter circumstance, to a certain extent, can contribute to a decrease in the likelihood of occurrence of a maximum of strength indicators, depending on the ratio of polymer components. In all cases, an increase in LDPE concentration over 50 wt. $\%$ is accompanied by a sharp decrease in strength properties. This is a state when, in the phase inversion, long-range order is, to a certain extent, violated during the formation of crystalline formations [12].

One of the important points in the study of composite materials based on a mixture of polymers is the use of vulcanizing agents that promote crosslinking of dissimilar macrochains which ultimately leads to forced compatibility of mixture components. Fig. 2 shows the curves of the dependence of the tensile yield stress of polymer mixtures on the sulfur concentration. The initial object of the study was to focus on a mixture of HDPE + LDPE + 1.0 wt. \% titanium dioxide.

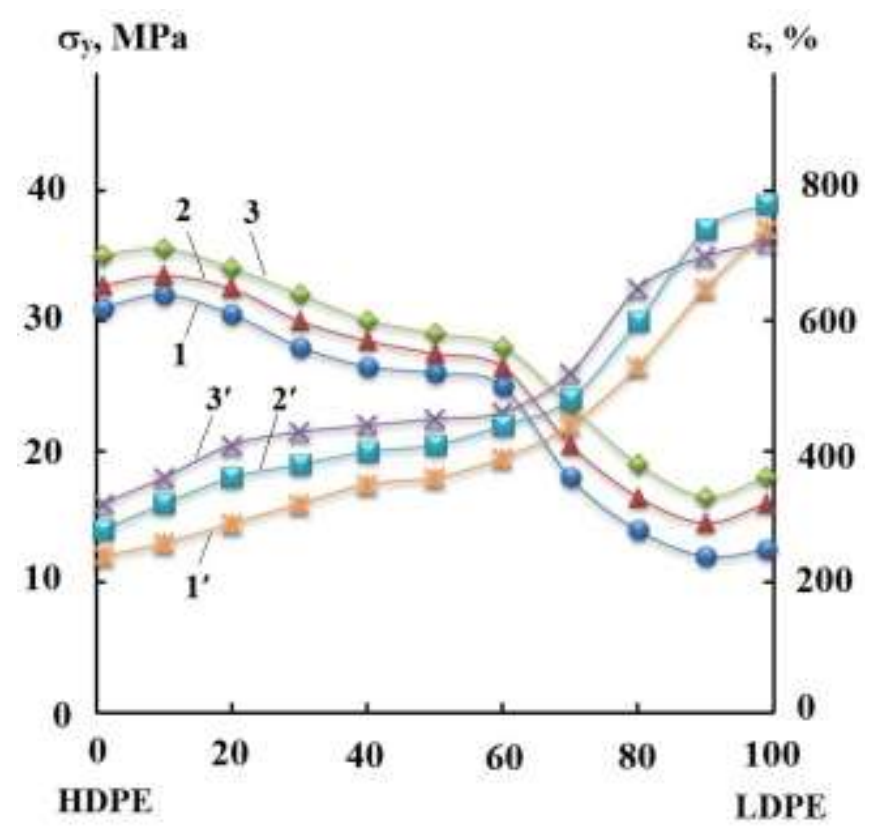

Fig. 2. Influence of HDPE / LDPE ratio and sulfur concentration on tensile yield strength $(1,2,3)$ and elongation $\left(1^{\prime}, 2^{\prime}, 3^{\prime}\right)$ of vulcanized compositions: 1- 1.0; 2- 3.0; 3- 5.0 wt. \%

Comparing curves 1, 2 and 3 in this Fig., it can be established that on Fig. 2 the influence of HDPE / LDPE ratio and sulfur concentration on tensile yield strength $(1,2,3)$ and elongation $(1 ', 2$ ', 3') of vulcanized compositions: 1- 1.0; 2-
$3.0 ; 3-\quad 5.0 \quad$ wt. $\%$ sulfur vulcanization contributes to a significant increase in $\sigma_{\mathrm{y}}$ of the samples in the entire range of HDPE / LDPE ratios. 
The sulfur concentration varied in the range of 1-5 wt. \%. As can be seen from Fig. 2, at all ratios of the mixture components, the maximum strength is practically not observed The latter circumstance is associated with the fact that when sulfur vulcanization occurs in the melt, the process of chemical crosslinking proceeds uniformly throughout the entire volume of the samples. In addition, one should take into account that sulfur is an eight-membered cycle which, under the influence of temperature and shear stress on rollers, leads to the formation of radicals that, as a rule, promotes the breaking of double bonds or the attachment in the $\alpha$-position to the double bond. In polyethylene, double bonds are relatively insignificant and characterized mainly by terminal, transvinylene vinyl groups [2,3]. Therefore, the use of sulfur in excess of 5.0 wt. \% produced no desirable effect in improving the properties. The appearance of eight-membered sulfur bridges between polyethylene macrochains simultaneously contribute to their strengthening and improvement of deformation characteristics.

Another important aspect of research into polymer mixtures was the consideration of such thermophysical and technological characteristics as heat resistance, melting point and MFI of samples. In this case, MFI characterizes the technological feature of the processing of composite materials. Analyzing the data presented in Table 1, it can be established that sulfuric vulcanization contributes to some increase in the heat resistance of the samples. It is characteristic that the melting point of the samples practically undergoes no significant changes. This circumstance is explained as being due to the fact that the melting point is a thermodynamic index which fixes the physical process of melting of crystalline formations under the influence of temperature. In sulfur vulcanizates, the derivatograph shows the value of the melting temperature in the sections of crystalline formations of composite materials free from crosslinking. The difference manifests itself in a slight decrease in the intensity of the melting peak as sulfur concentration increases.

As noted above, sulfur vulcanization proceeds at the site of break of a relatively small number of double bonds, and therefore, contributes to the formation of a sparsely reticulated spatial structure. This is confirmed by results of the MFI study of composite materials. As can be seen from Table 1, as the sulfur concentration increases, a regular decrease in the MFI of the samples is observed. At the same time, the MFI values of vulcanized polymer mixtures remain at a level sufficient for their processing by injection molding and extrusion methods and for obtaining structural products with a given structure and properties.

Table 1. Influence of sulfur concentration on thermophysical and technological parameters of composite materials based on HDPE / LDPE mixtures.

\begin{tabular}{|c|c|c|c|c|}
\hline № & $\begin{array}{c}\text { Formulation of composition, } \\
\text { wt. \% }\end{array}$ & $\begin{array}{c}\text { Heat resistance, } \\
{ }^{\circ} \mathrm{C}\end{array}$ & $\begin{array}{c}\text { Melting point, } \\
{ }^{\circ} \mathrm{C}\end{array}$ & $\begin{array}{c}\text { MFI, } \\
\mathrm{g} / 10 \mathrm{~min} .\end{array}$ \\
\hline 1 & $\mathrm{HDPE}+20 \mathrm{LDPE}+1.0 \mathrm{TiO}_{2}$ & 132 & 139 & 5.6 \\
2 & $\mathrm{HDPE}+20 \mathrm{LDPE}+1.0 \mathrm{TiO}_{2}+1.0 \mathrm{~S}$ & 132 & 139 & 4.1 \\
3 & $\mathrm{HDPE}+20 \mathrm{LDPE}+1.0 \mathrm{TiO}_{2}+3.0 \mathrm{~S}$ & 134 & 139 & 2.5 \\
4 & $\mathrm{HDPE}+20 \mathrm{LDPE}+1.0 \mathrm{TiO}_{2}+5.0 \mathrm{~S}$ & 135 & 140 & 1.3 \\
5 & $\mathrm{HDPE}+50 \mathrm{LDPE}+1.0 \mathrm{TiO}_{2}$ & 119 & 132 & 4.9 \\
6 & $\mathrm{HDPE}+50 \mathrm{LDPE}+1.0 \mathrm{TiO}_{2}+1.0 \mathrm{~S}$ & 120 & 132 & 3.8 \\
7 & $\mathrm{HDPE}+50 \mathrm{LDPE}+1.0 \mathrm{TiO}_{2}+3.0 \mathrm{~S}$ & 122 & 132 & 2.3 \\
8 & $\mathrm{HDPE}+50 \mathrm{LDPE}+1.0 \mathrm{TiO}_{2}+5.0 \mathrm{~S}$ & 123 & 133 & 0.9 \\
9 & $\mathrm{HDPE}+80 \mathrm{LDPE}+1_{0} \mathrm{TiO}_{2}$ & 105 & 118 & 4.2 \\
10 & $\mathrm{HDPE}+80 \mathrm{LDPE}+1.0 \mathrm{TiO}_{2}+1.0 \mathrm{~S}$ & 106 & 118 & 2.9 \\
11 & $\mathrm{HDPE}+80 \mathrm{LDPE}+1.0 \mathrm{TiO}_{2}+3.0 \mathrm{~S}$ & 107 & 118 & 1.6 \\
12 & $\mathrm{HDPE}+80 \mathrm{LDPE}+1.0 \mathrm{TiO}_{2}+5.0 \mathrm{~S}$ & 109 & 118 & 0.5 \\
\hline
\end{tabular}

S- sulfur 
Thus, on the basis of the studies performed it can be stated that the loading of a structurant-titanium dioxide into the composition of HDPE+LDPE-based polymer mixtures improves their strength parameters and elongation at break. Sulfur vulcanization of polymer mixtures makes it possible to substantially ensure high strength characteristics of polymer mixtures while maintaining the thermophysical properties at a satisfactory level. As a result of sulfur vulcanization of polymer mixtures, a slight decrease in the MFI of the samples is observed maintaining its value at a level sufficient for obtaining structural materials on their basis by injection molding and extrusion.

\section{References}

1. Berlin A.A., Volfson S.A., Oshman V.G. The principles of creating composite materials. Moscow : Chemistry Publ., 1990, $240 \mathrm{p}$.

2. Ermakov S.N., Kerber M.L., Kravchenko T.P. Chemical modification and mixing of polymers in reactive extrusion. Plasticheskie massy. 2007, no.10, pp. 3241. (In Russian).

3. Kalistratova L.F., Egorova V.A. Ordering of the amorphous phase as one of the characteristics of the supramolecular structure of an amorphous crystalline polymer. Materialovedenie. 2019, no. 1, pp. 3-9. (In Russian).

4. Simonov-Emelyanov I.D. Construction of structures in dispersed-filled polymers and properties of composite materials. Plasticheskie massy. 2015, vol. 9-10, pp. 29-36. (In Russian).

5. Dyakonov A.A., Danilova S.N., Vasilev A.P., Ohlopkova A.A., Sleptsova S.A., Vasileva A.A. Study of the effect of sulfur, diphenylguanidine and 2-mercaptobenzthiazole on the physicomechanical properties and structure of ultra-high molecular weight polyethylene. Perspektivnye materialy. 2020, no.1, pp. 43-53. (In Russian).

6. Mashkov Yu.K., Kalistratova L.F., Kropotin O.V. Development of methods for the formation of effective structural-phase states of polymer composites based on PTFE. Plasticheskie massyi. 2017, no.3-4, pp. 12-14. (In Russian).

7. Anour S., Abdalah K., Rabea E., Shalh A., Hassan E., Wael E. The influence of LDPE content on the mechanical properties of HDPE/LDPE blends. Res. \& Dev. Material Sci. 2018, vol. 7, no. 5, 7p.

8. Kakhramanov N.T., Mustafaeva F.A., Arzumanova N.B., Guliev A.D. Kinetic regularities of the crystallization of composite materials based on a mixture of polyethylene of high and low density. Materialovedenie. 2019, no. 5, pp. 43-48. (In Russian).

9. Kakhramanov N.T., Mustafaeva F.A., Osipchik V.S., Arzumanova N.B., Khamedova L.H., Lyalyaeva R.N. Rheological properties of polymer blends based on low and high density polyethylene. Kompozityi i nanostrukturyi Composites \& nanostructures. 2018, vol. 10, no. 4(40), pp. 166-170. (In Russian).

10. Kakhramanov N.T., Guseynova Z.N., Lalayeva R.N., Xamedova L.X., Gadjieva R. Sh.. Thermomechanical properties of dynamically vulcanized thermoelastoplastics based on polyolefins and ethylenepropylene-diene rubber. Kompozity $i$ nanostruktury - Composites and Nanostructures, 2018, vol.10, no. 3(39), pp. 123-128. (In Russian).

11. Ulitin N.V., Deberdeev T.R. Some viscoelastic properties of crosslinked network polymers. Theoretical calculation. Plasticheskie massy. 2012, no. 2, pp. 3439. (In Russian).

12. Guseynova Z.N. Modification of PE+PP composites with various rubbers in the presence of tellurium. Plasticheskie massy. 2011, no. 4, pp. 43-45. (In Russian). 


\title{
AŞAĞI Və YUXARI SIXLIQLI POLİETİLEN QARIŞIQLARININ Və ONLARIN ӘSASINDA OLAN MODİFIKASIYYA OLUNMUŞ KOMPOZİSIYYALARIN FİİKİ-MEXANİKİ XASSəLəRİ
}

\author{
F.Ә. Mustafayeva, N.T. Qəhrəmanov, İ.Ә. İsmayılov, L.X. Xamedova, *Q.S. Martınova \\ Azarbaycan Milli Elmlar Akademiyası Polimer Materialları İnstitutu \\ AZ 5004, Sumqayıt şəhəri, S. Vurğun kü̧̧əsi, 124 \\ *Azarbaycan Milli Elmlar Akademiyası Neft va Qaz Institutu \\ AZ1000, Bakı şəh., F.Omirov küç., 9; e-mail: najaf1946@ rambler.ru
}

\begin{abstract}
Məqalədə polimer komponentlərin - yuxarı və aşağı sıxlıqlı polietilenin əsas fiziki-kimyəvi xassələrə təsiri nəzərdən keçirilmişdir. Polimer qarışıqların dartılmada axıcılıq həddi və möhkəmlik həddi, nisbi uzanma kimi xüsusiyyətləri öyrənilmişdir. Polimer qarışıqda aşağı sıxlıqlı polietilenin miqdarı artdıqca asılılıq əyrilərində iki maksimumun alındığı göstərilmişdir. Bu maksimumlar qarışıqda aşağı sıxlıqlı polietilenin 5.0 və 50 kütlə \% miqdarına uyğun olmuşdur. 1 kütlə \% quruluşəmələgətiricinin-titan dioksidin polimer qarışıqların tərkibinə daxil edilməsi polimer komponentlərin praktiki olaraq bütün nisbətlərində möhkəmlik göstəricilərinin və nisbi uzanmasının nəzərəçarpacaq artmasına kömək etmişdir. Kükürd tikici agentinin kompozisiya materialların fiziki-kimyəvi və istilikfiziki xassələrinə təsiri öyrənilmișdir. Polimer qarıșıqda kükürdün miqdarının 1.0 kütlə \%-dən 5.0-ə qədər artırılması ilə nümunələrin dartılmada axıcılıq həddi, nisbi uzanma və istiliyədavamlılığının qanunauyğun artdığı müəyyən olunmuşdur. Həmçinin vulkanlaşdırıcı agentin miqdarı artdıqca polimer kompozisiyaların orintisinin axıcılıq göstəricisinin azalması qeyd olunmuşdur. Titan dioksid və kükürdün təsiri zamanı polimer qarışıqda gedən proseslərin nəzəri əsaslandırılması verilmişdir.
\end{abstract}

Açar sözlər: aşağı sixlıqlı polietilen, yüksək sıxlıqlı polietien, quruluşəmələgətirici, vulkanlaşma, istiliyədavamlılıq, ərimə temperaturu, kükürd.

\section{ФИЗИКО-МЕХАНИЧЕСКИЕ СВОЙСТВА СМЕСЕЙ ПОЛИЭТИЛЕНА ВЫСОКОЙ И НИЗКОЙ ПЛОТНОСТИ И МОДИФИЦИРОВАННЫХ КОМПОЗИЦИЙ НА ИХ ОСНОВЕ \\ Ф.А. Мустафаева, Н.Т. Кахраманов, И.А. Исмайлов, Л.Х. Хамедова, *Г.С. Мартынова}

\author{
Институт Полимерных Материалов Наииональной АН Азербайджана \\ AZ 5004, г.Сумгайьлт, ул. С.Вургуна 124 \\ *Институт Нефти и Газа Национальной АН Азербайджана \\ AZ1000, Баку, ул. Ф. Амирова, 9; e-mail: najaf1946@rambler.ru
}

В работе рассмотрено влияние соотношения полимерных компонентов - полиэтилена высокой плотности и полиэтилена низкой плотности на основные физико-механические свойства. Изучены такие свойства полимерных смесей, как предел текучести при растяжении, разрушающее напряжение и относительное удлинение. Показано, что по мере увеличения содержания полиэтилена низкой плотности в полимерной смеси на кривых зависимости проявляются два небольших максимума. Эти максимумы соответствуют 5.0 и 50\%масс. содержанию полиэтилена низкой плотности в смеси. Введение $1.0 \%$ масс структурообразователя - двуокиси титана в состав полимерных смесей способствует заметному возрастанию их прочностных показателей и относительного удлинения практически при всех соотношениях полимерных компонентов. Изучено влияние сшивающего агента - серы на основные физико-механические и теплофизические свойства композиционных материалов. Установлено, что с увеличением содержания серы от 1.0 до $5.0 \%$ масс в полимерной смеси наблюдается закономерное повышение предела текучести при растяжении, относительного удлинения и теплостойкости образцов. Наряду с этим отмечено некоторое снижение показателя текучести расплава полимерных композиций с ростом концентрации вулканизующего агента. Дается теоретическое обоснование процессам, протекающими в полимерных смесях в процессе воздействия двуокиси титана и серы.

Ключевые слова: полиэтилен низкой плотности, полиэтилен высокой плотности, структурообразователь, вулканизация, теплостойкость, температура плавления, сера. 